\title{
Vitamin Content of Butters
}

$\mathrm{B}$ UTTER is an important source of vitamins A and $\mathrm{D}$ in the diet, but the amounts present vary with the feeding of the cow and also, in the case of vitamin $D$, with the amount of sunlight to which the animal is exposed. Summer butter is more potent than winter butter. Since much of the butter consumed in Great Britain is imported, it is essential to know whether it can compare in vitamin value with the home-produced article and whether storage has any influence upon its potency. Experiments carried out during the past few years by Crawford, Perry and Zilva on Australian, New Zealand and English butters add to our information on this subject.*

The tests were carried out on young rats : for vitamin $\mathbf{A}$ assays they were given a diet deficient in this vitamin, but containing irradiated hardened vegetable oil, dried yeast and lemon juice to supply vitamins $\mathrm{D}, \mathrm{B}$ and $\mathrm{C}$ respectively. When growth had ceased, small doses of butter were given daily for four weeks and the growth rate compared with that of other animals supplied with 3-5 drops of cod liver oil daily. For vitamin $D$ tests the animals were kept on McCollum's rachitogenic diet No. 3143: the prophylactic method was used and the positive controls were given 3-5 drops of cod liver oil daily. All the animals were killed after 28 days and the ash content of the dried fat-free bones of the hindlegs estimated. The ratio of ash to organic residue was worked out and the degree of protection from rickets expressed as a percentage of the protection

* Medical Research Council. Special Report Series, No. 175: Vitamin Content of Australian, New Zealand and English Butters. By M. E. F. Crawford, E. O. V. Perry and S. S. Zilva. (London : H.M. Stationery Office, 1932.) 18. net. given by the cod liver oil. Three doses of butter were usually employed, $0.1,0.2$ and $0.6 \mathrm{gm}$. daily, and six rats were put on each dose.

The English butters tested were obtained in winter from cows stalled but also given up to $8 \mathrm{oz}$. cod liver oil a day. $0.1 \mathrm{gm}$. daily produced about as good growth in the depleted rats as the dose of cod liver oil given to the positive controls, whilst $0.6 \mathrm{gm}$. daily gave almost complete protection from rickets. The butters were retested after 5-20 months storage at $-10^{\circ}$ to $-12^{\circ} \mathrm{C}$.' There appeared to have been some loss of vitamin A after 20 months', but no, or only slight, loss of vitamin D after 5 months', storage.

Summer and winter butters from Now Zealand and two summer butters from Australia were examined. The latter were as potent as the English butters, and the New Zealand summer butter was not significantly less active. The New Zealand winter butter, however, contained less vitamin $\mathbf{D}$ than the others. Storage at a low temperature for periods up to two years had little effect on the vitamin content of these butters: the New Zealand summer butter showed some loss of vitamin $\mathrm{D}$ in this time.

Further conclusions from this research are that the breed of the dairy herd, the district in which it is pastured, and the process of neutralising acid creams before churning, have no effect on the vitamin content of the butter from Australia and New Zealand. Butters from these Dominions therefore may be recommended to fill deficiencies in the home supply. The preface to the report states that imports from Australia and New Zealand have already increased from 20 per cent of our total imports in 1913 to 44 per cent in 1932 .

\section{University Statistics of Great Britain}

$\mathrm{T}$ HE tabular statements compiled annually by the University Grants Committee from returns submitted by universities and university colleges in Great Britain and published by H.M. Stationery Office* are models of what such publications should be-lucid, comprehensive, concise. Here is set out on twenty pages a conspectus of fifty-five institutions, comprising all important aspects susceptible of statistical presentation. The tables are preceded by a brief introductory note directing attention to some salient features of the returns with comments on their significance.

Students are classified according to sex, domicile, dwelling place (hostel, lodgings, home) during term, age on admission, grade, subjects of study, degrees and diplomas obtained. Of the total number of full-time students $(35,751$ men and 12,759 women) in attendance in 1931-32, approximately 23 per cent were in London, 21 per cent in Oxford and Cambridge, 21 per cent in the provincial universities of the midlands and northern England, 23 per cent in Scottish universities, $6 \frac{1}{2}$ per cent in Wales and 5 per cent in Bristol, Reading, Southampton and Exeter. Some 4,400, nearly 10 per cent, came from abroad, that is, from homes outside the British Isles,

* University Grants Committee. Returns from Universities and University Colleges in Receipt of Treasury Grant. Academic Year as did likewise 1,500 (more than 10 per cent) of the part-time students. Of these 5,900 visitors from abroad, more than half (2,609 full-time and 726 parttime) were from countries within the British Empire, whilst 1,741 full-time and 775 part-time students were foreigners. The following table gives the numbers of full-time students from abroad at those seats of learning to which they resorted in the greatest numbers and the ratios of such visitors to the total numbers of full-time students in attendance :

\begin{tabular}{|c|c|c|c|c|c|}
\hline & & $\begin{array}{l}\text { (1) B.E. } \\
\text { overseas }\end{array}$ & $\begin{array}{l}\text { (2) Foreign } \\
\text { countries }\end{array}$ & $\begin{array}{l}\text { (1) and } \\
\text { (2) }\end{array}$ & $\begin{array}{l}\text { Per cent } \\
\text { of tota }\end{array}$ \\
\hline London . . & . & 1116 & 607 & 1723 & 15 \\
\hline Univ. Coll. & & 230 & 131 & 361 & 18 \\
\hline Sch. of Economic & & 133 & 168 & 301 & 37 \\
\hline Imp. Coll. & . & 177 & 47 & 224 & 22 \\
\hline King's Coll. & . & 121 & 59 & 180 & 12 \\
\hline Medical Schools & . & 300 & 132 & 432 & 13 \\
\hline Edinburgh & . & 369 & $\mathrm{I} 82$ & 551 & 15 \\
\hline Oxford & . & 306 & 235 & 541 & 11 \\
\hline Cambridge & 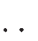 & 342 & 187 & 529 & 9 \\
\hline Glasgow . & & 133 & 79 & 212 & 4 \\
\hline Manchester & & 65 & 68 & 133 & 5 \\
\hline St. Andrews & 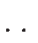 & 14 & 102 & 116 & 14 \\
\hline Birmingham & & 24 & 82 & 106 & 7 \\
\hline Leeds $\quad \ldots$ & . & 65 & 32 & 97 & 6 \\
\hline
\end{tabular}


At a time when world economic problems and the quest of internationally acceptable solutions have assumed the tragic urgency of riddles of the Sphinx, it is interesting that more than a third of the London School of Economics students were from abroad and more than a fifth from foreign countries. The Imperial College (of Science and Technology) justified its name by drawing 17 per cent of its students from the outlying parts of the Empire. The number of such students at Oxford was smaller than at Cambridge, notwithstanding the imperial mission assigned to Oxford by Rhodes as the alma mater of the Rhodes scholars from the dominions. The large proportion of foreigners at St. Andrews and Birmingham is noticeable.

Closely associated with the question of the resort to our universities of students from abroad is the pursuit of advanced studies in them. Of the total number of full-time students 2,399 ( 7 per cent more than in the previous year) were engaged in research or other advanced studies and they were congregated chiefly at London (Imperial Coll. 241, Univ. 234, King's 131, School of Economics 118), Cambridge (372), Oxford (241), Edinburgh (145), Manchester (139), Birmingham (83). Part-time advanced students were numerous at London (Univ. Coll. 192, Birkbeck 178, School of Economics 99, King's 84, Univ. Coll. Hosp. Medical School 80), Liverpool (217), Glasgow (105).

University libraries are confronted everywhere at the present time with the difficulty of coping with the increasing number and cost of periodicals. The returns disclosed the fact that last year the ratio between expenditures on the purchase of periodicals and of books respectively rose from $2: 5$ to more than $3: 5$. The University Grants Committee points to the danger lest "What we may call the 'Periodicals interest' may by force of circumstances become so firmly established that it will in effect succeed in securing for itself the first call on limited library funds, and that only what is left over after its demands have been met will be available for the purchase of books proper."

University finances seem to have stood the strain of hard times well, thanks to timely limitation of commitments and concentration upon essentials, and the deficits of all the institutions, ten in number, of which the expenditure exceeded income amounted only to just over $£ 11,000$. The largest of these lapses (it was at Aberdeen) was but $£ 3,684$.

\section{Fundamental Laws of Optical Rotatory Power}

$\mathrm{T}$ HE February issue of the Berichte der deutschen chemischen Gesellschaft contains an interesting account, by Dr. Werner Kuhn of Heidelberg, of a theory of optical rotatory power which he has developed with conspicuous success in recent years. A mathematical treatment of the problem has also been worked out by Dr. Kuhn and was published three years ago in the Transactions of the Faraday Society.

It is pointed out that in spite of the general application of the principle that optical activity is associated with structural dissymmetry, attempts to predict the magnitude or even the sign of the rotation of a new compound are singularly unsuccessful, and a more complete knowledge of the physical aspects of rotatory power seems to be necessary for a better understanding of this elusive problem. Kuhn appears to have recognised that absorption bands in the visible and ultra-violet regions constitute the physical equivalents of the asymmetric molecule of the chemist. Each of these bands furnishes a definite contribution to the rotatory power, which is the algebraic sum of all such contributions, though some of these may be negligible in value. Thus the observed rotation is in reality an additive function and each individual part of the molecule may contribute its quota.

In 1896 , Cotton showed that the rotatory power of optically active compounds becomes abnormal in the region of absorption and that it is associated with circular dichroism. Now circular dichroism is caused by the unequal absorption of $d$ - and $l$-circularly polarised light. Kuhn has developed this idea and has shown that a quantitative relation exists between circular dichroism and rotatory power; that is, either of these values can be calculated from the other, as illustrated by the case of chromium potassium tartrate dissolved in a solution of potassium hydroxide. Cotton investigated this solution in the visible region. In $1931 \mathrm{Kuhn}$ and Szabo re-determined the values for both properties and extended their observations also into the ultra-violet region of the spectrum.

Still more striking evidence is furnished by the much more complex case of $\beta$-octyl nitrite, which Kuhn and Lehmann described in 1932. Here the curve of circular dichroism consists of several undu. lations and is partly positive, partly negative. From this highly complex curve a correspondingly complex curve of rotatory dispersion has been calculated and the values which are thus obtained are shown graphically to approximate very closely to experimental results.

Thus the rotatory power is the sum of the positive and negative contributions of several bands, which in the visible region are nearly but not completely balanced. Now general absorption is due to the presence in the molecule of chromophore groups, but optical rotation is not produced unless the electronic vibrations in a chromophore group are coupled with those of another group (which is probably nonabsorbent or colourless), in such a way that when one vibration proceeds, say, from left to right, the other proceeds from back to front. Coupling of two vibrations in this fashion produces a difference in the absorption of $d$ - and $l$-circularly polarised light and therefore dichroism, which in its turn gives rise to optical rotatory power. Thus in order that an absorption band may contribute rotatory power, it is essential that the electronic vibrations originating from a chromophore group should be capable of transmission to another part of the molecule; and the effect is greatest when this chromophore group lies near the 'centre of asymmetry'. Should these bands lie in the visible or early ultra-violet region of the spectrum, the effect on rotatory power will be very marked.

The author also deals with the vicinal effect on rotatory power of chemical changes near the absorption band. This aspect of the problem forms the subject of a separate contribution by Dr. K. Freudenberg. 